\title{
Synthesis and Characterization of 4-Phenacyloxy Benzaldehyde Derivatives
}

\author{
UNDRI RASTUTI',2, DWI SISWANTA ${ }^{1}$ and JUMINA ${ }^{1 *}$ \\ ${ }^{1}$ Departement of Chemistry, Faculty of Mathematics and Natural Sciences, \\ Universitas Gadjah Mada Sekip Utara Bulaksumur, Yogyakarta 55281, Indonesia. \\ 2Departement of Chemistry, Faculty of Mathematics and Natural Sciences, \\ Universitas Jenderal Soedirman Jl. dr. Soeparno Karangwangkal, Purwokerto 5312, Indonesia. \\ *Corresponding author E-mail: jumina@ugm.ac.id \\ http://dx.doi.org/10.13005/ojc/320515
}

(Received: September 23, 2016; Accepted: October 15, 2016)

\begin{abstract}
Some new 4-phenacyloxy benzaldehyde derivatives (PB1-PB4) have been synthesized through substitution reaction of 4-hydroxy-benzaldehyde derivatives and phenacyl bromide derivatives using triethylamine as the catalyst in the micellar media at room temperature. Physical data from IR, ${ }^{1} \mathrm{H}-\mathrm{NMR},{ }^{13} \mathrm{C}-\mathrm{NMR}$ and GC-MS were used to characterize the compounds structure. The yield of the PB1-PB4 compounds was $46-66 \%$ with purity of $91-96 \%$. The compounds have been tested as an antibacterial agent.
\end{abstract}

Keywords: Phenacyl; phenacyloxy benzaldehyde; micellar, IR, ${ }^{1} \mathrm{H}-\mathrm{NMR},{ }^{13} \mathrm{C}-\mathrm{NMR}, \mathrm{GC}-\mathrm{MS}$.

\section{INTRODUCTION}

Ether compounds have the same functional group -COC-. Compounds that can be categorized as ether is the aryl ether, allyl ethers, phenolic ethers, phenacyl ether, and polyether. Phenolic ethers or aromatic ether is a compound containing oxygen ether with a phenyl group at one end and the aryl, alkyl, benzyl, allyl, vinyl, and others at the threshold of another. In the agrochemical field, phenolic ethers are used as pesticides, herbicides, and fungicides ${ }^{1-3}$. Phenolic ether is also applied in chemical engineering ${ }^{2}$, as a food coloring agent, perfume, and polymer additives ${ }^{4}$. In the pharmaceutical industry ether derivatives act as antibiotics for example Teicoplanin ${ }^{5-7}$ and vancomycin ${ }^{8-11}$; bouvardin as antitumor $^{12-13}$, and peptide $\mathrm{K}-13$ as an example antiviral ${ }^{14-16}$. Polybrominated diphenyl ether (PBDE) is applied as the polymer for plastic products and electronic ${ }^{17-19}$. Some ether is used as a reactant in the synthesis of organic compounds. Benzyl ethers act as intermediates in reactions such as rearrangement Sigmatropic Claisen and Cope rearrangements ${ }^{20}$. 
Aldehyde group is known to have effective antimicrobial properties and are typically used for high-level disinfection in health care environments ${ }^{21-23}$. The antimicrobial efficacy of two aldehyde based biocides (glutaraldehyde, GTA, and orthophthalaldehyde, OPA) and two surfactants (cetyltrimethyl ammonium bromide, CTAB, and sodium dodecyl sulfate, SDS) was tested against planktonic Pseudomonas fluorescens ${ }^{24}$. Various types of aldehydes, both aliphatic and aromatic, are also being used as the ingredients to synthesized calixarenes. Calix[4]resorcinarenes is a compound which could be obtained from the reaction of an aldehyde with resorcinol. Some aldehydes which have been used for the synthesis of calix[4] resorcinarene is acetaldehyde ${ }^{25}$, hydroxybenzaldehyde ${ }^{26}$, 4-hydroxy-3-methoxybenzaldehyde $^{27}$, anisaldehyde ${ }^{28}$, cinamaldehyde ${ }^{29}$, heptanal ${ }^{30}$ and 4-allyloxy-3-methoxy benzalde-hyde ${ }^{31}$

Several methods have been published for synthesis of ether ${ }^{32}$ i.e. Williamson ether synthesis ${ }^{33}$, bimolecular dehydration ${ }^{34}$, Ullman ether synthesis ${ }^{35-}$ ${ }^{36}$, transition metal-free synthesis of aryl ethers ${ }^{37}$ and room-temperature ionic liquid-promoted Williamson synthesis of ethers ${ }^{38}$. Meanwhile, the using of a catalyst copper(II) was also reported in the synthesis of ether from aliphatic alcohols and potassium organotrifuoroborate salts ${ }^{39}$. Other methods were also presented such as microwave-assisted without a catalyst ${ }^{39}$ and solvent-free micellar condition ${ }^{41-42}$.

Various methods have been made to synthesis phenacyl phenyl ether. For example, to obtain phenacyl phenyl ether from phenacyl bromide and phenol in the presence of sodium carbonate with a water-acetone medium. Phenacyl ether also can be synthesized from phenacyl bromide in ethanol with potassium iodide ${ }^{43}$. Another reported method was synthesis of phenacyl aryl ether/phenacyl phenyl ether/phenolic ether from phenacyl bromide with an aromatic alcohol and triethylamine in micellar media. ${ }^{44-48}$. A series of naphthyl ether has been synthesized through a reaction with micellar media between naphthol and phenacyl or benzyl bromide, with triethylamine in $70 \%$ methanol/water $(\mathrm{v} / \mathrm{v})$ at $30^{\circ} \mathrm{C} .{ }^{45}$ Polyhdric phenolic phenacyl ethers were synthesized by micellar mediated reaction with phenacyl and its substituted phenacyl bromide. The biological importance of phenacyl ethers also had been reviewed. ${ }^{45-47}$

In this work, we presented the synthesis of some aldehyde derivatives (4-phenacyloxybenzaldehyde). In fact, 4-phenacyloxy-benzaldehyde is one of ether derivatives which could be obtained via Williamson etherification reaction. The method being used in this work was following the synthesis of phenacyl-ether with triethylamine in micellar media. The 4-phenacyloxy-benzaldehyde compound in this study was afforded from the reaction of 4-hydroxy benzaldehyde and 3-methoxy-4-hydroxy benzaldehyde (vanillin) with phenacyl bromide and 4'-bromo-phenacyl-bromide as shown in Figure 1.

\section{MATERIAL AND METHODS}

The materials used in this research were 4-hydroxy-benzaldehyde, 4-hydroxy-3-methoxy benzaldehyde (vanillin), 2-bromoacetophenone (phenacyl bromide), and 2,4'-dibromo acetophenone (4'-bromo-phenacyl bromide). Triethylamine was used as the catalyst and sodium dodecyl sulfate/SDS (micellar) as co-surfactant. All chemical and solvent were purchased from Merck (except distilled water) and used without further purification.

Structure identifications were performed using Infrared Spectrophotometer (IR, ShimadzuPrestige 21), Gas chromatography-mass spectrometry (GC-MS, Shimadzu QP-2010S). Proton nuclear magnetic resonance spectrometer ( ${ }^{1} \mathrm{H}-\mathrm{NMR}$, JEOL MY-500 MHz), and carbon nuclear magnetic resonance spectrometer $\left({ }^{13} \mathrm{C}-\mathrm{NMR}\right.$, JEOL MY-500 MHz) was performed in $\mathrm{CDCl}_{3}-\mathrm{d}_{6}$ with tetramethylsilane (TMS) as the internal standard.

\section{General Procedure for Synthesis of Phenacyloxy Benzaldehyde PB1-PB4 ${ }^{44-47}$}

Aldehyde (10 $\mathrm{mmol})$ was dissolved in methanol or ethanol and was added $5 \mathrm{~mL}$ triethylamine. This solution was added dropwise to the mixture of substituted acetophenone (phenacyl bromide) $(10 \mathrm{mmol})$ in methanol or ethanol with addition of micellar solution. The mixture was stirred at room temperature for 6-20 hours. The reaction was monitored using TLC with ethyl acetate and n-hexane (3:1) as an eluent. After completion, the 
reaction mixture was poured into ice water, and the precipitate formed was filtered, washed, dried and recrystallized from ethanol (ethanol:water $=1: 1$ ). This product was named phenacyloxy benzaldehyde (PB). Micellar media was made by dissolving 0.06 $\mathrm{g}(2.08 \mathrm{mmol}) \mathrm{SDS}$ in the mixture of methanol:water $(70: 30, v / v)$ and stirred for 1 hour.

\section{Synthesis of 4-phenacyloxy benzaldehyde (PB1)}

Prepared by above method from 4-hydroxy benzaldehyde $(1.22 \mathrm{~g}, 10 \mathrm{mmol})$ and phenacyl bromide $(1.99 \mathrm{~g}, 10 \mathrm{mmol})$ using methanol at room temperature for 7 hours. Purification: recrystallization from ethanol. Yield: 60\%; yellowish-white (beige) solid; m.p.: $120^{\circ} \mathrm{C}$; FT-IR ( $\left.\mathrm{cm}^{-1}\right): 3070$ (CH aromatics), 2981 ( $\mathrm{CH}$ aliphatic), 2846 and 2762 ( $\mathrm{CH}$ aldehydes), 1689 ( $\mathrm{C}=\mathrm{O}), 1581$ ( $\mathrm{C}=\mathrm{C}), 1218$ (COC). ${ }^{1} \mathrm{H}-\mathrm{NMR}$ ( $\delta$ ppm, $\left.\mathrm{CDCl}_{3}-\mathrm{d}_{6}, 500 \mathrm{MHz}\right): 10.09(1 \mathrm{H}, \mathrm{s}, \mathrm{CHO} /$ aldehyde $(\mathrm{Ha})) ; 7.02$ up to $8.00(\mathrm{H}$, aromatic groups); $5.39\left(2 \mathrm{H}, \mathrm{s}\right.$, methylene $\left.-\mathrm{CH}_{2}-(\mathrm{Hg})\right) .{ }^{13} \mathrm{C}-\mathrm{NMR}(\delta \mathrm{ppm}$, $\left.\mathrm{CDCl}_{3}-\mathrm{d}_{6}, 500 \mathrm{MHz}\right)$ : $193.32(\mathrm{C}=\mathrm{O}(\mathrm{Cj})), 190.79$ $(\mathrm{CHO}(\mathrm{Ca})), 70.77$ (methylene carbon $\left.-\mathrm{CH}_{2}-(\mathrm{Ci})\right)$, 162.85 (aromatic carbon adjacent to oxygen ether (Ch)), 115.13 up to 134.30 (aromatic carbons). GCMS chromatograms: m/z 240, purity: $96.56 \%$.

\section{Synthesis 4-phenacyloxy 3-methoxy benzaldehyde (PB2)}

Prepared by above method from 4-hydroxy 3-methoxy benzaldehyde $(1.52 \mathrm{~g}, 10 \mathrm{mmol})$ and phenacyl bromide $(1.99 \mathrm{~g}, 10 \mathrm{mmol})$ using methanol at room temperature for 5 hours. Purification: recrystallization from ethanol. Yield: $66 \%$; yellowish- white (beige) solid; m.p.: $126^{\circ} \mathrm{C}$; FT-IR $\left(\mathrm{cm}^{-1}\right)$ : 3062 (CH aromatics), 2924 ( $\mathrm{CH}$ aliphatic), 2846 and 2738 ( $\mathrm{CH}$ aldehydes), 1689 (C=O), 1589 (C=C), 1219 (COC). GC-MS chromatograms: m/z 270, purity: 95.73\%. ${ }^{1} \mathrm{H}-\mathrm{NMR}\left(\delta \mathrm{ppm}, \mathrm{CDCl}_{3}-\mathrm{d}_{6}, 500 \mathrm{MHz}\right)$ : $9.83(1 \mathrm{H}, \mathrm{s}, \mathrm{CHO} /$ aldehyde $(\mathrm{Ha})) ; 6.85$ up to 7.99 ( $\mathrm{H}$, aromatic groups); $5.47\left(2 \mathrm{H}, \mathrm{s}\right.$, methylene $-\mathrm{CH}_{2}-$ $(\mathrm{Hg})) ; 3.96\left(3 \mathrm{H}, \mathrm{s},-\mathrm{OCH}_{3}(\mathrm{Hf})\right) .{ }^{13} \mathrm{C}-\mathrm{NMR}(\delta \mathrm{ppm}$, $\left.\mathrm{CDCl}_{3}-\mathrm{d}_{6}, 500 \mathrm{MHz}\right): 193.32(\mathrm{C}=\mathrm{O}(\mathrm{Cj})), 190.90$ $(\mathrm{CHO}(\mathrm{Ca})), 71.48$ (methylene carbon $-\mathrm{CH}_{2}-(\mathrm{Ci})$ ), $56.30\left(\mathrm{OCH}_{3}(\mathrm{Cg})\right), 149.90$ (aromatic carbon adjacent to oxygen ether $(\mathrm{CH}), 110.16$ up to 134.17 (aromatic carbons). GC-MS chromatograms: m/z 270, purity: $95.73 \%$.

\section{Synthesis 4-(4'-bromo)-phenacyloxy benzaldehyde (PB3)}

Prepared by above method from 4-hydroxy benzaldehyde $(0.61 \mathrm{~g} 5 \mathrm{mmol})$ and 4'-bromo phenacyl bromide (1.39 g $5 \mathrm{mmol}$ ) using ethanol at room temperature for 20 hours. Purification: recrystallization from ethanol:water (1:1). Yield: $66 \%$; yellowish-white (beige) solid; m.p.: $98^{\circ} \mathrm{C}$; FT-IR $\left(\mathrm{cm}^{-1}\right): 3070$ ( $\mathrm{CH}$ aromatics), 2924 ( $\mathrm{CH}$ aliphatic), 2800 and 2731 ( $\mathrm{CH}$ aldehydes), $1674(\mathrm{C}=\mathrm{O}), 1597$ $(\mathrm{C}=\mathrm{C}), 1219$ (COC). ${ }^{1} \mathrm{H}-\mathrm{NMR}\left(\delta \mathrm{ppm}, \mathrm{CDCl}_{3}-\mathrm{d}_{6}, 500\right.$ $\mathrm{MHz})$ : $9.89(1 \mathrm{H}, \mathrm{s}, \mathrm{CHO} /$ aldehyde $(\mathrm{Ha})) ; 7.01$ up to $7.85(\mathrm{H}$, aromatic groups); $5.32(2 \mathrm{H}, \mathrm{s}$, methylene $\left.-\mathrm{CH}_{2}-(\mathrm{Hg})\right) \cdot{ }^{13} \mathrm{C}-\mathrm{NMR}\left(\delta \mathrm{ppm}, \mathrm{CDCl}_{3}-\mathrm{d}_{6}, 500 \mathrm{MHz}\right)$ : $192.82(\mathrm{C}=\mathrm{O}(\mathrm{Cj})), 190.64(\mathrm{CHO}(\mathrm{Ca})), 70.59$ (methylene carbon $-\mathrm{CH}_{2}-(\mathrm{Ci})$ ), 162.87 (aromatic carbon adjacent to oxygen ether (Ch)), 115.08 up to 133.10 (aromatic carbons). GC-MS chromatograms: m/z 318, purity: $90.24 \%$.

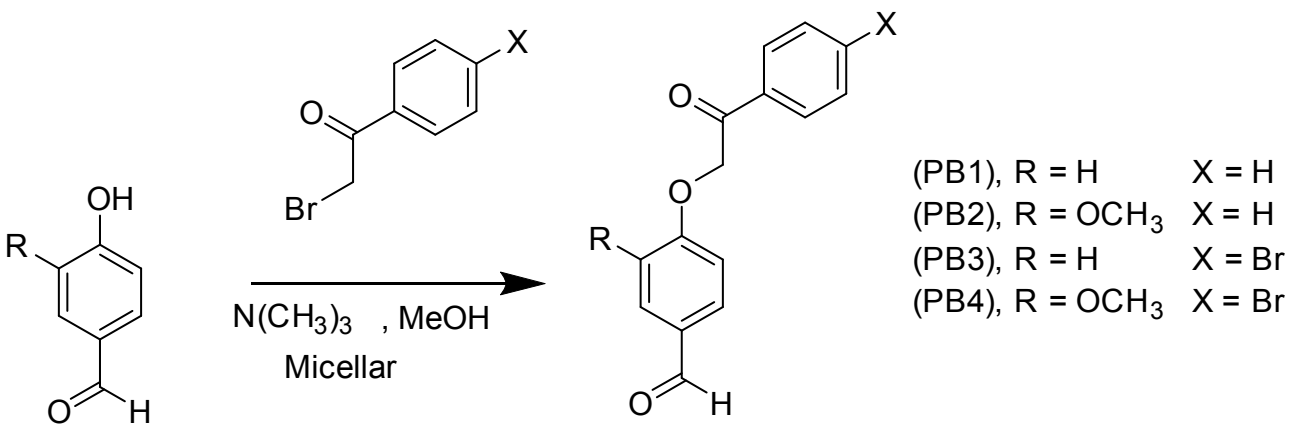

4-hydroxy benzaldehyde

(1) 4-phenacyloxy benzaldehyde (PB)

(2)

Fig. 1: Scheme of synthesis of 4-phenacyloxy benzaldehyde derivatives 
Synthesis 4-(4'-bromo)-phenacyloxy 3-methoxy benzaldehyde (PB4)

Prepared by above method from 4-hydroxy 3-methoxy benzaldehyde $(0.76 \mathrm{~g}, 5 \mathrm{mmol})$ and 4'-bromo phenacyl bromide (1.39 g, $5 \mathrm{mmol})$ using ethanol at room temperature for 20 hours. Purification: recrystallization from ethanol:water (1:1). Yield: 46.3\%; yellowish-white (beige) solid; m.p.: $108^{\circ} \mathrm{C}$; FT-IR $\left(\mathrm{cm}^{-1}\right): 3093$ ( $\mathrm{CH}$ aromatics), $2924(\mathrm{CH}$ aliphatic), 2839 and 2731 ( $\mathrm{CH}$ aldehydes), 1689 $(\mathrm{C}=\mathrm{O}), 1589(\mathrm{C}=\mathrm{C}), 1226(\mathrm{COC}) .{ }^{1} \mathrm{H}-\mathrm{NMR}(\delta \mathrm{ppm}$, $\left.\mathrm{CDCl}_{3}-\mathrm{d}_{6}, 500 \mathrm{MHz}\right): 9.85(1 \mathrm{H}, \mathrm{s}, \mathrm{CHO} /$ aldehyde $(\mathrm{Ha})) ; 6.87$ up to $7.87(\mathrm{H}$, aromatic groups); $5.39(2 \mathrm{H}$, $\mathrm{s}$, methylene $\left.-\mathrm{CH}_{2}-(\mathrm{Hg})\right)$; $3.95\left(3 \mathrm{H}, \mathrm{s},-\mathrm{OCH}_{3}(\mathrm{Hf})\right)$. ${ }^{13} \mathrm{C}-\mathrm{NMR}\left(\delta \mathrm{ppm}, \mathrm{CDCl}_{3}-\mathrm{d}_{6}, 500 \mathrm{MHz}\right): 192.59(\mathrm{C}=\mathrm{O}$ (Cj)), $190.74(\mathrm{CHO}(\mathrm{Ca})), 71.46$ (methylene carbon $-\mathrm{CH}_{2}-(\mathrm{Ci})$ ), $56.55\left(\mathrm{OCH}_{3}(\mathrm{Cg})\right.$ ), 150.48 (aromatic carbon adjacent to oxygen ether (Ce)), 109.92 up to 132.97 (aromatic carbons). GC-MS chromatograms: m/z 350, purity: $90.09 \%$.

\section{Anti-microbial activity assay}

Antibacterial Test against pathogens was conducted according to the proposed method by Jacobsen et al. On the surface of a petri dish, it was poured with $50 \mathrm{ml}$ of media pads. Once it solidified, the test medium for bacterial pathogens, which have been added by $1 \%$ of culture pathogens (Staphylococcus aureus FNCC 0091, Bacillus cereus FNCC 0040, Escherichia coli 0091 and Salmonella thiphymurium FNCC 157) was poured into as much as $50 \mathrm{~mL}$. After it becomes harden, made the diameter pitting around $10 \mathrm{~mm}$. A total of $100 \mathrm{~mL}$ of test compound solution (concentration of 1250, 2500, $5000,7500$ and $10000 \mathrm{ppm}), 100 \mathrm{ppm}$ of tetracycline as a positive control and also negative control, DMSO $99.9 \%$, was added to the wells. After the addition of the test compound, it was then incubated at $37^{\circ} \mathrm{C}$ for 24 hours and then the inhibitory zone was measured using a caliper. Inhibition zone was measured by means of reducing the overall diameter with diameter ring.

\section{RESULTS AND DISCUSSION}

This work has been successfully synthesizing four aldehyde derivatives, i.e. 4-phenacyloxybenzaldehyde (PB1), 4-phenacyloxy-3-methoxybenzaldehyde (PB2), 4-(4'-bromo) phenacyloxybenzaldehyde (PB3) and 4-(4'-bromo)-phenacyloxy3-methoxy benzaldehyde (PB4), through modification of synthesis method of aryl phenacyl ether in micellar<smiles>[R]c1cc(C=O)ccc1O[13CH2]CCCN(C)C</smiles>

(1)<smiles>[X]c1ccc(C(=O)COc2ccc(C=O)cc2[R])cc1</smiles>

(4)<smiles>[X]c1ccc(C(=O)CBr)cc1</smiles>

$-\mathrm{Br}$

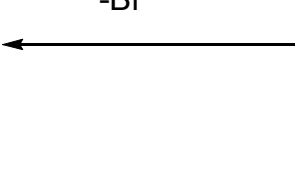

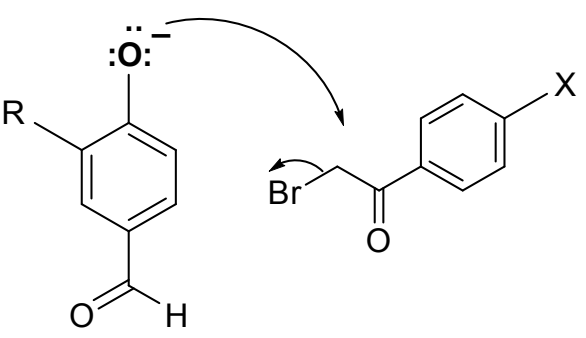

(2)<smiles>[X]c1ccc(C(=O)C(Br)C(Br)Oc2ccc(C=O)cc2[R])cc1</smiles>

(3)

Fig. 2: Reaction mechanism of synthesis 4-phenacyloxy benzaldehyde derivatives 
media ${ }^{44}$. The modification was performed either in the reactant, on the solvent being used and also the reaction time.

The reaction occurs via Williamson etherification mechanism between aldehyde compounds (4-hydroxy-benzaldehyde, 4-hydroxy 3-methoxy-benzaldehyde) with phenacyl bromide (2-bromoacetophenone) or 4'-bromo phenacyl bromide (2,4'- dibromoacetophenone). Triethylamine which was used as a catalyst could protonate the hydrogen atom of the hydroxyl group and in advance could be substituted by phenacyl bromide. Hydroxyl group from the aldehyde derivatives could form phenolate salts when reacted with

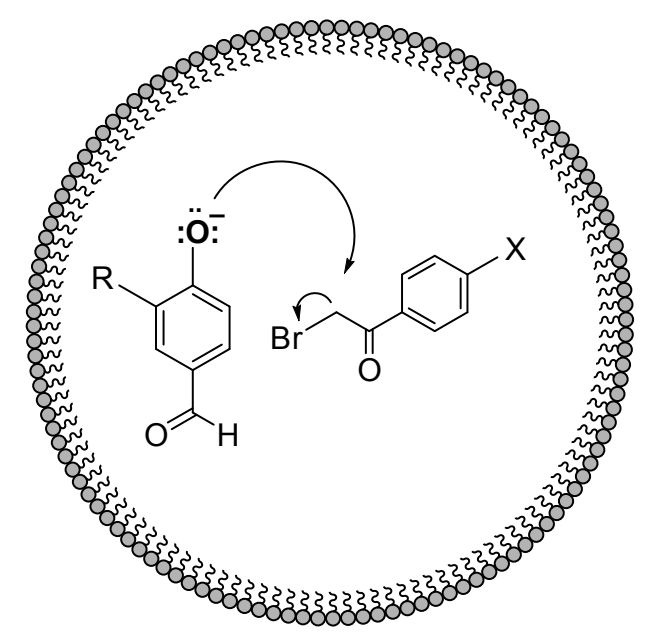

Fig. 3: Stabilization of phenolate in medium micellar<smiles>[X]c1ccc(C(=O)COc2ccc(C=O)cc2[R])cc1I</smiles>

Fig. 4: Protons of phenacyloxy benzaldehyde derivative compound PB1-PB4 bases, nucleophiles or hydride, which has higher solubility in water or in organic solvents to form a nucleophile species. This nucleophile would attack the carbon $\alpha$ of phenacyl bromide and as a bromide is a good leaving group, it would lead to obtaining of phenacyloxy benzaldehyde ether derivatives (PB1-PB4). The reaction mechanism can be seen in Figure 2.

This reaction also occurs in micellar medium, the micelle used was SDS (sodium dodecyl sulfate). SDS acts as surfactants, surfactants are usually organic compounds that are amphipathic, as they contain both hydrophobic groups ("tails") and hydrophilic groups ("heads") ${ }^{49}$. The $-\mathrm{COCH} 2 \mathrm{Br}$ part of the $\mathrm{PhCOCH} 2 \mathrm{Br}$ and $\mathrm{OH}$ group of $\mathrm{PhOH}$ (s) may be highly exposed in the hydrophilic region, whereas aromatic part of the reactants may be populated in the hydrophobic region of the micelles ${ }^{47}$. In this medium, the formation of the phenolate ion is stabilized more easily ${ }^{46}$. Illustration role micellar medium can be seen in Figure 3.

Characterization of PB1-PB4 from IR Spectra showed the absence of absorption at 3400 $\mathrm{cm}^{-1}$ which indicates the substitution of the hydroxyl group with phenacyl has successfully occurred. The IR spectra showed absorption at $3062-3093 \mathrm{~cm}^{-1}(\mathrm{CH}$ aromatics), 2924-2981 $\mathrm{cm}^{-1}$ (CH aliphatic), 28002846 and 2731-2762 $\mathrm{cm}^{-1}$ ( $\mathrm{CH}$ aldehydes), 1689$1674 \mathrm{~cm}^{-1}(\mathrm{C}=\mathrm{O}), 1597-1589 \mathrm{~cm}^{-1}(\mathrm{C}=\mathrm{C}), 1218-1226$ $\mathrm{cm}^{-1}(\mathrm{COC})$.<smiles>[X]c1ccc(C(=O)C(I)=Cc2ccc(C=O)cc2[R])c(C)c1</smiles>

Fig. 5: Carbons of phenacyloxy benzaldehyde derivative compound PB1-PB4 
The ${ }^{1} \mathrm{H}$-NMR spectra showed all of the compounds have signals at $\delta=9.83-10.09 \mathrm{ppm}$ (singlet, $1 \mathrm{H}$ ) which indicates of aldehyde group $(\mathrm{Ha})$ as seen in Figure 3. Oxygen is highly electronegative than carbon so the aldehyde proton would be more deshielded and could give a higher chemical shift. Proton resonance of methylene group $(\mathrm{Hg})$ appears at $\delta=5.32-5.47 \mathrm{ppm}$ (singlet, $2 \mathrm{H}$ ). Meanwhile, the protons of the aromatic ring appear at $\delta=6.85-8.00$ ppm. Separation of the signals (singlet, doublet or triplet) indicates the number of protons in the atom adjacent. Spectra from PB2 and PB4 compound with a methoxy group ( $\mathrm{Hf})$ showed a signal at $\delta=3.95-3.96 \mathrm{ppm}$ (singlet, $3 \mathrm{H}$ ).

Characterization of the product is then performed with ${ }^{13} \mathrm{C}$ NMR analysis to identify the represent of carbon at the product which could support the previous spectroscopic analysis. In the ${ }^{13} \mathrm{C}-N M R$ spectra, PB1 emerged with 10 peaks which indicate the existence of 10 kinds of carbon. As for PB2, PB3 and PB4, there were 13, 11 and 14 peaks respectively, which indicate for each 13,11 , and 14 types of carbon. Methylene carbon peak is shown at 70.59-71.48 ppm. The peak at 190.64-190.90 ppm indicates the carbon of aldehyde carbonyl group carbon, but carbon ketone carbonyl group is shown more downfield at 192.59-193.60 ppm. Especially for PB2 and PB4, the peak of methoxy carbon appeared at 56.30 and 56.55 ppm. The peak at 110.16-134.30 ppm belongs to the carbon of aromatic ring, but as for carbon of an aromatic ring adjacent to the ether oxygen appeared at 152.63-162.87 ppm.

\section{Anti-microbial activity}

Functional groups of a compound gave effect on antibacterial activity, the phenacyl ether compounds in the study showed no antibacterial activity. In the compounds, FB1 and FB4 showed inactive against Staphylococcus aureus, Bacillus cereus, Escherichia coliand Salmonella thiphymurium while for compounds FB2 and FB3 show inactive against Staphylococcus aureus, Escherichia coli, and Salmonella thiphymurium, but slightly active against bacteria Bacillus cereus. Phenacyl ether compound is inactive as antibacterial because the possibility of steric factors or antibacterial test methods is not appropriate.

\section{CONCLUSION}

In conclusion, four phenacyloxy benzaldehyde derivatives, PB1-PB4 have been successfully synthesized and characterized through various spectroscopic methods in a high yield and also purity. The synthesis involved the substitution reaction between 4-hydroxy-benzaldehyde derivative with phenacyl bromide derivative using triethylamine as a catalyst in micellar media at room temperature.

\section{REFERENCES}

1. Salunkhe, M.M., Thorat, M.T., Sande, A.V.R., Wadgaonkar P.P. Bull. Soc. Chem. Bel., 1994, 103(11), 691-693.

2. Ashok, P., Nimavat, K.S., Vyas, K.B. Pelagia Research Library, Der Pharmacia Sinica., 2011, 2(4), 26-32.

3. Özden, Ö.G., Taner, E., Hakan, G., Sulhiye, Y. Bioorg. Med. Chem. Lett., 2007, 17(8), 2233-2236.

4. Bales, B.R., Janda, D.K. J. Org. Chem., 1982, 47, 4374.

5. Evans, D.A., Peterson, G.S., Hintermann T., Katz, J.L. Am. Chem. Soc., 2001, 123, 12411.

6. Boger, D.L., Miyazaki, S., Kim S.H., Wu, J.H., Strittmatter, H., Wang, J.H., Mori, Y., Rogel,
O., Castle, S.L., McAtee, J.J., J. Am. Chem. Soc., 2000, 122: 7416.

7. Boger, D.L., Kim, S.H., Wu, J.H., Wang, J.H., Mori, Y., Rogel, O., Castle, S.L., McAtee, J.J. Angew. J. Am. Chem. Soc., 2001, 123, 1862.

8. Evans, D.A., Wood M.R., Trostter, B.W., Richardson, T.I., Barrow, J.C., Katz, J.L. Angew. Chem. Int. Ed., 1998, 37, 2700.

9. Evans, D.A., Dinsmore, C.J., Watson, P.S., Wood, M.R., Trostter, B.W., Richardson, T.I., Katz, J.L. Angew. Chem. Int. Ed., 1998, 37, 2704.

10. Nicolaou, K.C., Takaynagi, M,, Jain, N.F., Natrajan, S., Koumbis, A.E., Bando, T., Ramanjulu, J.M. Chem. Int. Ed., 1998, 37, 
2717.

11. Boger, D.L., Miyazaki, S., Kim, S.H., Wu, J.H., Oiselesur, O.L., Castle, S.L. J. Am. Chem. Soc., 1999, 121, 3226.

12. Hitotsuyanag, Y., Ishikawa, H., Naito, S., Takeya, K. Tetrahedron Lett., 2003, 44, 5901.

13. Boger, D.L., Patne, M.A., Zhou, J.J. J. Am. Chem. Soc., 1994, 116, 8544.

14. Janetka, J.W., Rich D.H. J. Am. Chem. Soc., 1997, 119, 6488.

15. Rao A.V.R., Chakraborty T.K., Reddy K.L., Rao A.S. Tetrahedron Lett., 1992, 33, 4799.

16. Bigot A., Bois M., Choussy., Zhu J. Tetrahedron Lett., 2000, 41, 4573.

17. Chen C.Y., Wang C.K., Shih Y.H. J. Environ. Sci. Heal. B., 2010, 45, 379-385.

18. Shih Y.H., Chou H.L., Peng Y.H. J. Hazard. Mater., 2012, 213(214), 341-346.

19. Jeyakumar, T., Kodisundaram, I.P., Kalaiarasi, I., Int. J. Chem. Tech. Res. 2015, 7(7), 31633170.

20. Donald, A.P., Stanislav, A.B., Svetlana, M.B., Susan, K.J., Tanja, W., Todd, B., Arvind, K., David, W.B., Karl, A., Werbovetz., Reto, B., Richard, R., Tidwell. Eur. J. Med. Chem., 2013, 67, 310-324.

21. McDonnell, G., Russell, A.D. Clin. Microbiol. Rev., 1999, 12, 147-179.

22. Rutala, W.A., Weber, D.J. Emerg. Infect. Dis., 2001, 7, 348-353.

23. Walsh, S.E., Maillard, J.Y., Russell, A.D., Catrenich, C.E., Charbonneau, D.L., Bartolo R.G. J. Hosp. Infect., 2003, 55, 98107.

24. Simoes, M., Pereira, M.O., Machado, I., Simoes, L.C., Vieira, M.J. J. Ind. Microbiol. Biotechnol., 2006, 33, 741-749.

25. Qi, F., Shi Wen, F. Chem. Res. Chinese. U., 2009, 25(5), 760-766.

26. Echigo., Masatoshi., Dai, O. Development of new phenylcalix[4]resorcinarene: its application to positive-tone molecular resist for EB and EUV lithography., Proc. SPIE., 2009, 7273: 72732Q.

27. Sardjono, R.E., Jumina., Nurwahidin, A.W., Taufik., Sastrohamidjojo, H., Santoso, S.J., Adsorption characteristics of $\mathrm{Pb}(\mathrm{II})$ onto C-4-Hydroxy-3-methoxyphenyl calix[4] resorcinarene in systems batch and fixed bed column, Proceeding of the International
Seminar on Chemistry., 2008, 419-425.

28. Utomo, S.B., Jumina., Siswanta, D., Mustofa, Kumar, N. Indones. J. Chem., 2011, 11(1), 1-8.

29. Sardjono, R.E., Dwiyanti, G., Aisyah, S., Khoerunnisa, F., The synthesis of calix[4] resorcinarene from cassia oil and its application for solid phase extraction of heavy metal $\mathrm{Hg}(\mathrm{II})$ and $\mathrm{Pb}(\mathrm{II})$. Prosiding Seminar Kimia Bersama UKM-ITB VIII., 2009.

30. Handayani, D.S., Amin, Z.A.A., Kusumaningsih, T., Masykur, A. Alchemy., 2014, 10(1), 49-53.

31. Kesuma, E.P., Jumina., Ohto, K., Siswanta, D. Orient. J. Chem., 2016, 32(2), 769-775.

32. Mandal, S., Swagata, M., Sumanta, K.G., Pintu, S., Aniruddha, G., Rumpa, S., Bidyut, S. RSC Adv., 2016, 6, 69605-69614.

33. Fuhrmann, E., Talbiersky, J. Org. Process. Res. Dev., 2005, 9, 206-211.

34. Yang, W., Xi, J., Zhang, B., Song, Q., Chen, Q., Mao, D. J. Catal., 2005, 230, 140-149.

35. Chang, J.W.W., Chee, S., Mak, S., Buranaprasertsuk, P., Chavasiri, W., Chan, P.W. Tetrahedron Lett., 2008, 49, 20182022.

36. Karthik, A.D., Geetha, K., Int. J. Chem. Tech. Res., 2015, 7(3), 1578-1585.

37. Lindstedt, E., Raju, G., Berit, O. Org. Lett., 15(23), 6070-6073.

38. More, S.V., Ardhapure, S.S., Naik, N.H., Bhusare, S.R., Jadhav, W.N., Pawar, R.P., Synth. Commun., 2005, 35, 3113-3118.

39. Hassan, J., Sevignon, M., Gozzi, C., Schulz, E., Lemaire, M. Chem. Rev., 2002, 102, 1359-1469.

40. Li, F., Wang, Q., Ding, Z., Tao, F., Org. Lett., 2003, 5, 169-2171.

41. Siswanto, C., Battal, T., Schuss, O.E., Rathman, J.F. Langmuir, 1997, 13(23), 60476052.

42. Battal, T., Siswanto, C., Rathman, J.F. Langmuir., 1997, 13, 6053-6057.

43. Fritz Kroenke., Gertrauae Gem W., Ahrenholz. J. Prakt. Chem., 1960., 11, 239.

44. Nallu, M., Selvakumar, R., Pillay, M.K. Indian. J. Chem., 1999, 38B, 1108-1110.

45. Fazal Mohamed, M.I., Aruna devi, S., J. Chem. Pharm. Res., 2010., 2(6), 296-300.

46. Fazal Mohamed, M.I., Durga Devi, G.K., 
Orient.J.Chem., 2011., 27(1), 233-237.

47. Durga Devi G.K., Fazal Mohamed, M.I. Pelagia Research Library-Der Chemica Sinica, 2012, 3(1), 71-75.

48. Kanase, S.M., Piste, P.B., Shevale, S.B. Int. J. Pharm. Sci. Rev. Res., 2013, 23(2), 03:
15-17.

49. Mishra, M., Muthuprasanna, P., Prabha, K.S., Rani, P.S., Babu, I.A.S., Sarath Chandiran, I., Arunachalam, G., Shalini, S. a review, Int. J. Pharm. Sci. Rev. Res., 2009, 1(4), 13541365. 